\title{
UTJECAJ KULTIVARA, INOKULACIJE SJEMENA I NAVODNJAVANJA NA AGRONOMSKA SVOJSTVA KRMNOG GRAŠKA U ISTOČNOJ HRVATSKOJ
}

\author{
INFLUENCE OF CULTIVAR, SEED INOCULATION AND \\ IRRIGATION ON AGRONOMIC PROPERTIES OF FIELD PEA IN \\ EASTERN CROATIA
}

Irena Rapčan, Daria Galić Subašić, Monika Marković, Sonja Grljušić

\section{SAŽETAK}

Provedeno je preliminarno istraživanje na dvije lokacije istočne Hrvatske s ciljem utvrđivanja utjecaja kultivara, inokulacije sjemena i navodnjavanja na poljsko nicanje, broj mahuna po biljci, broj zrna po mahuni, masu 1000 zrna, prinos zrna i sadržaj bjelančevina u zrnu. Značajnost učinaka ispitivanih faktora na istraživana svojstva bila je različita. Različita je bila i značajnost interakcija ispitivanih faktora. Podaci pokazuju da postoji mogućnost povećanja prinosa i kvalitete krmnog graška primjenom adekvatne agrotehnike, a prije svega inokulacije sjemena i navodnjavanja.

Ključne riječi: krmni grašak, kultivar, inokulacija sjemena, navodnjavanje, prinos zrna

\begin{abstract}
Preliminary field research was conducted at two locations of East Croatia in order to determine the impact of cultivar, seed inoculation and irrigation on field emergence, number of pods per plant, number of seeds per pod, 1000 grain mass, grain yield and seed protein content. Significance of tested factor effects on investigated traits varied. Differences in significance of tested interactions were also found. Results indicate that there is a possibility that the yield and quality of field pea may increase by applying appropriate agrotechnical measures and above all seed inoculation and irrigation.
\end{abstract}

Key words: field pea, cultivar, seed inoculation, irrigation, grain yield 
Irena Rapčan i sur.: Utjecaj kultivara, inokulacije sjemena i navodnjavanja na agronomska svojstva krmnog graška u istočnoj Hrvatskoj

\section{UVOD}

Krmni grašak (Pisum sativum L.) se 2014. godine u Republici Hrvatskoj uzgajao na 678 ha s prosječnim prinosom zrna od 2,10 $\mathrm{tha}^{-1}$ (Državni zavod za statistiku Republike Hrvatske, http://www.dzs.hr), što je značajno niže od prosječnog prinosa $\mathrm{u}$ EU koji je iste godine iznosio 2,63 $\mathrm{t} \mathrm{ha}^{-1}$ (www.fao.org.faostat). Slijedom toga nameće se pitanje mogu li se agrotehnikom (izborom kultivara, gnojidbom, primjenom inokulanta, navodnjavanjem i dr.) povećati prinosi u Hrvatskoj. Sukladno navodu Ackigoza i sur. (2009.) postoji značajan učinak genotipa, kao i njegove interakcije s okolinom na prinos zrna graška. Pri tome je prema Marufu i sur. (1995.) inokulacija bakterijom Rhizobium jeftinija i učinkovitija agronomska mjera za odgovarajuću snabdjevenost dušikom usjeva od primjene dušičnog gnojiva. Kako naglašavaju McPhee i Muehlbauer (2002.), prevladavajuća ograničenja za proizvodnju graška su temperatura zraka te količina i raspodjela oborina, pa su niži prinosi jarih kultura u Hrvatskoj vjerojatno i u vezi s nedostatkom vode i višim temperaturama zraka tijekom vegetacijske sezone (Kovačević i Kaučić, 2006.). Cilj ovog rada bio je ispitati utjecaj kultivara, inokulacije sjemena $i$ navodnjavanja na poljsko nicanje, broj mahuna po biljci, broj zrna po mahuni, masu 1000 zrna, prinos zrna i sadržaj bjelančevina u zrnu krmnog graška u uvjetima istočne Hrvatske sa svrhom procjene mogućnosti povećanja prinosa i kvalitete krmnog graška primjenom adekvatne agrotehnike.

\section{MATERIJAL I METODE}

Poljski pokus postavljen je 2014. godine na dvije lokacije istočne Hrvatske. $\mathrm{Na}$ lokaciji Antunovac $\left(45,53^{\circ} \mathrm{N}, 18,73^{\circ} \mathrm{S}, 89 \mathrm{~m}\right.$ nadmorske visine) tho je lesivirani semiglej na praporu, dok je na lokaciji Cerić $\left(45,46^{\circ} \mathrm{N}, 18,82^{\circ} \mathrm{E}, 87 \mathrm{~m}\right.$ nadmorske visine) eutrično smeđe na praporu (http://pedologija.com.hr). Pokus je postavljen po shemi split-split $\mathrm{s}$ tri faktora i četiri ponavljanja. Veličina osnovne parcele iznosila je $5 \mathrm{~m}^{2}$, razmak između parcela $20 \mathrm{~cm}$, a zaštitni pojas $1 \mathrm{~m}$. Grašak je posijan ručno na međuredni razmak od $20 \mathrm{~cm}$ i razmak u redu od $5 \mathrm{~cm}$, odnosno norma sjetve bila je 1000000 biljaka po hektaru. Prvi ispitivani faktor bio je kultivar jarog stočnog graška (K). Istraživanje je obuhvatilo dva kultivara Gold $\left(\mathrm{K}_{1}\right)$ i SW Crista $\left(\mathrm{K}_{2}\right)$, priznatih 2005. godine, slične mase 1000 zrna i namijenjenih proizvodnji zrna. Drugi faktor bio je inokulacija sjemena (I). 
Irena Rapčan i sur.: Utjecaj kultivara, inokulacije sjemena i navodnjavanja na agronomska svojstva krmnog graška u istočnoj Hrvatskoj

Oba kultivara posijana su bez inokulacije $\left(\mathrm{I}_{0}\right)$ i s inokulacijom inokulantom Nitrobakterin $\left(\mathrm{I}_{1}\right)$. Treći faktor bio je navodnjavanje $(\mathrm{N})$, a varijante su bile bez navodnjavanja $\left(\mathrm{N}_{0}\right)$ i s navodnjavanjem $\left(\mathrm{N}_{1}\right)$, pri čemu je rata navodnjavanja ovisila o uvjetima lokacije. Nakon nicanja utvrđeno je poljsko nicanje, a nakon žetve broj mahuna po biljci, broj zrna po mahuni, masa 1000 zrna i prinos zrna svake osnovne parcele i ponavljanja. NIT metodom (Infratec 1241 Analyzer, Foss Tecator) određen je sadržaj bjelančevina u zrnu iz prosječnog uzorka zrna po tretmanima. Dobiveni podaci obrađeni su u programu Statistica 13.2. (TIBCO Software Inc, 2017.). Prosjeci tretmana uspoređeni su korištenjem LSD testa. Osnovni klimatski pokazatelji u vegetaciji uspoređeni su s višegodišnjim prosjecima za obje lokacije (http://www.dhmz.htnet.hr). Prosjek srednjih temperatura zraka za mjesece vegetacije (travanj-srpanj 2014.) na lokaciji Antunovac iznosio je $17,9{ }^{\circ} \mathrm{C}$, što je na razini višegodišnjeg prosjeka za te mjesece (Tablica 1.).

Tablica 1. Srednja mjesečna temperatura zraka u 2014. godini i višegodišnji (1981.-2010.) prosjek za mjesece vegetacije krmnog graška za lokaciju Antunovac

Table 1 Mean monthly air temperatures in 2014 and long term average (1981.-2010.) for the months of growing field pea for the location Antunovac

\begin{tabular}{|l|c|c|c|c|}
\hline \multirow{2}{*}{ Mjesec } & \multicolumn{2}{|c|}{$\begin{array}{c}\text { Srednja mjesečna } \\
\text { temperatura zraka, }{ }^{\circ} \mathrm{C}\end{array}$} & \multicolumn{2}{c|}{$\begin{array}{c}\text { Mjesečna količina } \\
\text { oborine, mm }\end{array}$} \\
\cline { 2 - 5 } & 2014. & $1981 .-2010$. & 2014. & $1981 .-2010$. \\
\hline Travanj & 13,2 & 11,8 & 81,3 & 52,4 \\
\hline Svibanj & 16,1 & 17,1 & 161,4 & 63,9 \\
\hline Lipanj & 20,5 & 20,1 & 91,0 & 87,1 \\
\hline Srpanj & 21,8 & 22,0 & 66,4 & 56,0 \\
\hline & $\begin{array}{c}\text { Prosjek: } \\
17,9^{\circ} \mathrm{C}\end{array}$ & $\begin{array}{c}\text { Prosjek: } \\
17,8^{\circ} \mathrm{C}\end{array}$ & $\begin{array}{c}\text { Ukupno: } \\
400,1 \mathrm{~mm}\end{array}$ & \begin{tabular}{c} 
Ukupno: \\
\cline { 2 - 5 }
\end{tabular} \\
\hline
\end{tabular}

Raspored oborina po mjesecima iste godine razlikovao se od višegodišnjeg prosjeka, kao i ukupne oborine u vegetaciji $(400,1 \mathrm{~mm}$ nasuprot $259,4 \mathrm{~mm} \mathrm{u}$ prosjeku). U travnju je palo $81,3 \mathrm{~mm}$ oborina (za $28,9 \mathrm{~mm}$ više od prosjeka), dok su u svibnju bile značajno veće (za $97,5 \mathrm{~mm}$ ) od prosjeka za ovu lokaciju. 
Irena Rapčan i sur.: Utjecaj kultivara, inokulacije sjemena i navodnjavanja na agronomska svojstva krmnog graška u istočnoj Hrvatskoj

Zbog ovakvih količina i rasporeda oborina navodnjavanje graška provedeno je u jednom obroku od $30 \mathrm{~mm}$ krajem lipnja u fazi nalijevanja mahuna. Hod srednje mjesečne temperature zraka na lokaciji Cerić nije se značajno razlikovao od višegodišnjeg prosjeka (Tablica 2.). Ukupne oborine za mjesece vegetacije graška u višegodišnjem prosjeku iznose $308,8 \mathrm{~mm}$, dok je od travnja do srpnja 2014. godine ukupno palo $427,0 \mathrm{~mm}$ oborina. U travnju je palo $96,7 \mathrm{~mm}$ oborina (za $35,1 \mathrm{~mm}$ više od prosjeka). Razlika je još veća za svibanj u kojem višegodišnji prosjek iznosi $72,5 \mathrm{~mm}$, a 2014. godine palo je čak $179 \mathrm{~mm}$. U lipnju je zabilježeno 49,6 mm manje oborina od višegodišnjeg prosjeka $(111,2$ $\mathrm{mm}$ ), što je rezultiralo kraćim razdobljem suše, koje se poklopilo s fazom cvatnje i formiranja mahuna kada je poljski grašak najosjetljiviji na nedostatak vlage. Zbog toga je grašak navodnjavan u dva obroka od $40 \mathrm{~mm}$. U jesen 2013. godine obavljeno je oranje na obje lokacije. Tanjuranje i dopunska obrada tla obavljeni su krajem ožujka odnosno početkom travnja 2014. godine, a sjetva 11. travnja (Antunovac) i 12. travnja (Cerić) iste godine. Početkom svibnja uočeno je nicanje na obje lokacije, a sredinom lipnja početak cvatnje. Gnojidba nije provedena, kao ni zaštita od korova, bolesti i štetnika, jer nije uočen izraženiji napad korova i bolesti. Berba zrelih mahuna obavljena je 14. srpnja na lokaciji Antunovac i dan kasnije na lokaciji Cerić.

Tablica 2. Srednja mjesečna temperatura zraka u 2014. godini i višegodišnji (1981.-2010.) prosjek za mjesece vegetacije krmnog graška za lokaciju Cerić

Table 2 Mean monthly air temperatures in 2014 and long term average (1981.-2010.) for the months of growing field pea for the location Cerić

\begin{tabular}{|c|c|c|c|c|}
\hline \multirow{2}{*}{ Mjesec } & \multicolumn{2}{|c|}{$\begin{array}{l}\text { Srednja mjesečna } \\
\text { temperatura zraka, }{ }^{\circ} \mathrm{C}\end{array}$} & \multicolumn{2}{|c|}{$\begin{array}{l}\text { Mjesečna količina } \\
\text { oborine, } \mathrm{mm}\end{array}$} \\
\hline & 2014. & 1981.-2010. & 2014. & 1981.-2010. \\
\hline Travanj & 13,4 & 12,3 & 96,7 & 61,6 \\
\hline Svibanj & 16,4 & 17,6 & 179,0 & 72,5 \\
\hline Lipanj & 20,8 & 20,6 & 61,6 & 111,2 \\
\hline \multirow[t]{2}{*}{ Srpanj } & 22,4 & 22,6 & 89,7 & 63,4 \\
\hline & $\begin{array}{l}\text { Prosjek: } \\
18,3^{\circ} \mathrm{C}\end{array}$ & $\begin{array}{l}\text { Prosjek: } \\
18,3^{\circ} \mathrm{C}\end{array}$ & $\begin{array}{l}\text { Ukupno: } \\
\text { 427,0 mm }\end{array}$ & $\begin{array}{l}\text { Ukupno: } \\
\text { 308,8 mm }\end{array}$ \\
\hline
\end{tabular}


Irena Rapčan i sur.: Utjecaj kultivara, inokulacije sjemena i navodnjavanja na agronomska svojstva krmnog graška u istočnoj Hrvatskoj

\section{REZULTATI I RASPRAVA}

Prosječno poljsko nicanje iznosilo je 63,38\% na lokaciji Antunovac i $61,02 \%$ na lokaciji Cerić. Učinak kultivara i navodnjavanja na lokaciji Antunovac bio je na razini značajnosti od $\mathrm{p}=0,01$ (Tablica 3.). Na lokaciji Cerić učinak kultivara bio je značajan na $\mathrm{p}=0,01$, a navodnjavanje na $\mathrm{p}=0,05$. Interakcija kultivara $\mathrm{i}$ inokulacije sjemena bila je na razini $\mathrm{p}=0,05$, a ona kultivara i navodnjavanja na razini $\mathrm{p}=0,01$. Ova značajnost manja je od one koje nalaze neki autori (Kovač, 1994., Rapčan, 2002., 2006.). Na broj mahuna po biljci (lokacija Antunovac) značajan učinak imala je inokulacija sjemena i interakcija inokulacije i navodnjavanja $(\mathrm{p}=0,01)$ te interakcija kultivara $\mathrm{i}$ navodnjavanja $(\mathrm{p}=0,05)$ (Tablica 4.). Suprotan slučaj bio je na lokaciji Cerić, gdje su kultivar i navodnjavanje imali značajan učinak $(\mathrm{p}=0,01)$ na broj mahuna po biljci, a i njihova interakcija je bila značajna na istoj razini. Broj mahuna u ovom istraživanju kretao se od 2,27 do 3,08 ovisno o lokaciji i tretmanu. Ove vrijednosti su značajno niže od onih koje dobivaju Rapčan i sur. (2003.) u dvogodišnjim istraživanjima (4,68 do 5,71 mahuna po biljci). Na lokaciji Antunovac značajno veći broj zrna po mahuni $(p=0,05)$ postigao je kultivar Gold $(4,75)$ u odnosu na 4,31 kultivara SW Crista (Tablica 5.). Značajno veće vrijednosti $(\mathrm{p}=0,05)$ dobivene su na lokaciji Cerić $(4,85$ za Gold i 5,07 za SW Cristu). Učinak inokulacije i navodnjavanja, kao i interakcija inokulacije i navodnjavanja bili su značajni $(\mathrm{p}=0,01)$. Poggio i sur. (2005.) navode da je broj zrna po mahuni postojan između skupina kultivara. Ayaz i sur. (2004.b) navode 5,1 i 5,2 zrna po mahuni graška u dvogodišnjem istraživanju, što je nešto više u odnosu na rezultate ovog istraživanja (4,31-5,44 zrna po mahuni ovisno o tretmanu pokusa), vjerojatno kao posljedica različitosti kultivara u pokusu i okolišnih uvjeta istraživanja. Učinak kultivara $\mathrm{i}$ inokulacije sjemena na masu 1000 zrna na obje lokacije bio je značajan $(\mathrm{p}=0,01)$ (Tablica 6.). Na lokaciji Antunovac pokazale su se značajnima interakcija kultivara i navodnjavanja $((p=0,05)$ te inokulacije i navodnjavanja $(p=0,01)$. Izuzev interakcije kultivara, inokulacije i navodnjavanja, sve testirane interakcije na lokaciji Cerić bile su značajne $(\mathrm{p}=0,01)$. 
Irena Rapčan i sur.: Utjecaj kultivara, inokulacije sjemena i navodnjavanja na agronomska svojstva krmnog graška u istočnoj Hrvatskoj

Tablica 3. Srednje vrijednosti poljskog nicanja krmnog graška (\%) za svaki tretman po lokacijama s pripadajućim F-testom i LSD $(p=0,05$ i $p=0,01)$

Table 3 Average values of field emergence of the field pea (\%) for each treatment per locations with belonging $F$-test and LSD (at $p=0.05$ and $p=0.01$ )

\begin{tabular}{|c|c|c|c|c|c|c|}
\hline Faktor/ Lokacija & \multicolumn{3}{|c|}{ Antunovac } & \multicolumn{3}{|c|}{ Cerić } \\
\hline Kultivar (K): & \multicolumn{3}{|c|}{$\begin{array}{l}60,13 \\
66,63 \\
\end{array}$} & \multicolumn{3}{|c|}{$\begin{array}{l}59,63 \\
62,60\end{array}$} \\
\hline F-test: & \multicolumn{3}{|c|}{$43,613^{* *}$} & \multicolumn{3}{|c|}{$19,120 * *$} \\
\hline $\begin{array}{r}\operatorname{LSD}_{0,05} \\
0,01 \\
\end{array}$ & \multicolumn{3}{|c|}{$\begin{array}{l}2,753 \\
2,031 \\
\end{array}$} & \multicolumn{3}{|c|}{$\begin{array}{l}1,839 \\
1,357 \\
\end{array}$} \\
\hline $\begin{array}{l}\text { Inokulacija } \\
\text { sjemena (I): }\end{array}$ & \multicolumn{3}{|c|}{$\begin{array}{l}62,63 \\
64,13 \\
\end{array}$} & \multicolumn{3}{|c|}{$\begin{array}{l}60,44 \\
61,69\end{array}$} \\
\hline F-test: & \multicolumn{3}{|c|}{2,323} & \multicolumn{3}{|c|}{3,614} \\
\hline $\begin{array}{r}\operatorname{LSD}_{0,05} \\
0,01 \\
\end{array}$ & \multicolumn{3}{|c|}{$\begin{array}{l}2,753 \\
2,031 \\
\end{array}$} & \multicolumn{3}{|c|}{$\begin{array}{l}1,839 \\
1,357 \\
\end{array}$} \\
\hline $\begin{array}{r}\text { Navodnjavanje (N): } \mathrm{N}_{0} \\
\mathrm{~N}_{1}\end{array}$ & \multicolumn{3}{|c|}{$\begin{array}{l}61,31 \\
65,44\end{array}$} & \multicolumn{3}{|c|}{$\begin{array}{l}60,19 \\
61,64\end{array}$} \\
\hline F-test: & \multicolumn{3}{|c|}{$17,565 * *$} & \multicolumn{3}{|c|}{$7,084^{*}$} \\
\hline $\begin{array}{r}\operatorname{LSD}_{0,05} \\
0,01 \\
\end{array}$ & \multicolumn{3}{|c|}{$\begin{array}{l}2,753 \\
2,031\end{array}$} & \multicolumn{3}{|c|}{$\begin{array}{l}1,839 \\
1,357\end{array}$} \\
\hline Interakcije: & F-test & $\mathrm{LSD}_{0,05}$ & $\mathrm{LSD}_{0,01}$ & F-test & $\mathrm{LSD}_{0,05}$ & $\mathrm{LSD}_{0,01}$ \\
\hline $\mathrm{K} \times \mathrm{I}$ & 0,000 & 3,893 & 2,873 & $7,084 *$ & 2,601 & 1,919 \\
\hline $\mathrm{K} \times \mathrm{N}$ & 3,629 & 3,893 & 2,873 & $14,458 * *$ & 2,601 & 1,919 \\
\hline $\mathrm{I} \times \mathrm{N}$ & 0,790 & 3,893 & 2,873 & 0,904 & 2,601 & 1,919 \\
\hline $\mathrm{K} \times \mathrm{I} \times \mathrm{N}$ & 0,403 & 5,506 & 4,063 & 2,928 & 3,678 & 2,714 \\
\hline
\end{tabular}

$\mathrm{K}_{1}=$ Gold, $\mathrm{K}_{2}=\mathrm{SW}$ Crista; $\mathrm{I}_{0}=$ bez inokulacije sjemena, $\mathrm{I}_{1}$ = inokulacija sjemena;

$\mathrm{N}_{0}=$ bez navodnjavanja, $\mathrm{N}_{1}=$ navodnjavanje; * $\mathrm{p}=0,05$ razina značajnosti, $* * \mathrm{p}=0,01$ razina značajnosti

Masa 1000 zrna se kretala od 178,18 g do 249,35 g ovisno o lokaciji i tretmanu pokusa. Ove vrijednosti su u skladu s vrijednostima (od 125,7 do više od 250 g) koje navode različiti autori (Rapčan i sur., 2006., Stjepanović i sur., 2012., Krizmanić, 2016.). Najniži prinos zrna na lokaciji Antunovac ostvaren je tretmanom bez inokulacije sjemena $\left(1,21 \mathrm{t} \mathrm{ha}^{-1}\right)$, a najviši tretmanom inokulacije $\left(2,22 \mathrm{t} \mathrm{ha}^{-1}\right)$, kako je vidljivo iz Tablice 7. Na lokaciji Cerić isti tretmani postigli su 1,37 odnosno 2,43 $\mathrm{t} \mathrm{ha}^{-1}$. Značajan učinak $(\mathrm{p}=0,01)$ pokazuje inokulacija sjemena na lokaciji Antunovac, a na lokaciji Cerić svi ispitivani faktori. 
Irena Rapčan i sur.: Utjecaj kultivara, inokulacije sjemena i navodnjavanja na agronomska svojstva krmnog graška u istočnoj Hrvatskoj

Tablica 4. Prosječne vrijednosti broja mahuna po biljci krmnog graška za svaki tretman po lokacijama s pripadajućim F-testom i LSD $(p=0,05$ i p=0,01)

Table 4 Average values of pod numbers per field pea plant for each treatment over locations with belonging F-test and LSD (at $p=0.05$ and $p=0.01$ )

\begin{tabular}{|c|c|c|c|c|c|c|}
\hline Faktor/Lokacija & \multicolumn{3}{|c|}{ Antunovac } & \multicolumn{3}{|c|}{ Cerić } \\
\hline Kultivar (K): & \multicolumn{3}{|c|}{$\begin{array}{l}2,77 \\
2,57\end{array}$} & \multicolumn{3}{|c|}{$\begin{array}{l}2,96 \\
2,69\end{array}$} \\
\hline F-test: & \multicolumn{3}{|c|}{1,520} & \multicolumn{3}{|c|}{$53,090 * *$} \\
\hline $\begin{array}{r}\operatorname{LSD}_{0,05} \\
0,01\end{array}$ & \multicolumn{3}{|c|}{$\begin{array}{l}0,445 \\
0,328\end{array}$} & \multicolumn{3}{|c|}{$\begin{array}{l}0,102 \\
0,075\end{array}$} \\
\hline $\begin{array}{l}\text { Inokulacija } \\
\text { sjemena (I): }\end{array}$ & \multicolumn{3}{|c|}{$\begin{array}{l}2,27 \\
3,08\end{array}$} & \multicolumn{3}{|c|}{$\begin{array}{l}2,80 \\
2,85\end{array}$} \\
\hline F-test: & \multicolumn{3}{|c|}{$25,984 * *$} & \multicolumn{3}{|c|}{1,771} \\
\hline $\begin{array}{r}\operatorname{LSD}_{0,05} \\
0,01\end{array}$ & \multicolumn{3}{|c|}{$\begin{array}{l}0,328 \\
0,445\end{array}$} & \multicolumn{3}{|c|}{$\begin{array}{l}0,102 \\
0,075\end{array}$} \\
\hline $\begin{array}{r}\text { Navodnjavanje (N): } \mathrm{N}_{0} \\
\qquad \mathrm{~N}_{1}\end{array}$ & \multicolumn{3}{|c|}{$\begin{array}{l}2,83 \\
2,51\end{array}$} & \multicolumn{3}{|c|}{$\begin{array}{l}2,75 \\
2,90\end{array}$} \\
\hline F-test: & \multicolumn{3}{|c|}{4,106} & \multicolumn{3}{|c|}{$16,016^{* *}$} \\
\hline $\begin{array}{r}\operatorname{LSD}_{0,05} \\
0,01 \\
\end{array}$ & \multicolumn{3}{|c|}{$\begin{array}{l}0,445 \\
0,328\end{array}$} & \multicolumn{3}{|c|}{$\begin{array}{l}0,102 \\
0,075\end{array}$} \\
\hline Interakcije: & F-test & $\mathrm{LSD}_{0,05}$ & $\mathrm{LSD}_{0,01}$ & F-test & $\mathrm{LSD}_{0,05}$ & $\operatorname{LSD}_{0,01}$ \\
\hline $\mathrm{K} \times \mathrm{I}$ & 2,322 & 0,465 & 0,630 & 1,060 & 0,145 & 0,107 \\
\hline $\mathrm{K} \times \mathrm{N}$ & $7,174^{*}$ & 0,465 & 0,630 & $18,584 * *$ & 0,145 & 0,107 \\
\hline I x N & $17,264 * *$ & 0,465 & 0,630 & 3,677 & 0,145 & 0,107 \\
\hline $\mathrm{K} \times \mathrm{I} \times \mathrm{N}$ & 0,035 & 0,890 & 0,657 & 3,037 & 0,204 & 0,151 \\
\hline
\end{tabular}

$\mathrm{K}_{1}=$ Gold, $\mathrm{K}_{2}=\mathrm{SW}$ Crista; $\mathrm{I}_{0}=$ bez inokulacije sjemena, $\mathrm{I}_{1}=$ inokulacija sjemena;

$\mathrm{N}_{0}$ = bez navodnjavanja, $\mathrm{N}_{1}=$ navodnjavanje; $* \mathrm{p}=0,05$ razina značajnosti, $* * \mathrm{p}=0,01$ razina značajnosti

Na razini značajnosti od $\mathrm{p}=0,05$ bila je interakcija kultivara $\mathrm{i}$ navodnjavanja te na razini $p=0,01$ interakcija inokulacije sjemena $i$ navodnjavanja na lokaciji Antunovac. Interakcija kultivara $i$ inokulacije sjemena, kultivara $i$ navodnjavanja te inokulacije sjemena i navodnjavanja bile su značajne $(p=0,01)$ na lokaciji Cerić. 
Irena Rapčan i sur.: Utjecaj kultivara, inokulacije sjemena i navodnjavanja na agronomska svojstva krmnog graška u istočnoj Hrvatskoj

Tablica 5. Prosječne vrijednosti broja zrna po mahuni soje za svaki tretman po lokacijama s pripadajućim F-testom i LSD $(p=0,05$ i $p=0,01)$

Table 5 Average values of grain numbers per soybean pod for each treatment over locations with belonging F-test and LSD (at $p=0.05$ and $p=0.01$ )

\begin{tabular}{|c|c|c|c|c|c|c|}
\hline Faktor/ Lokacija & \multicolumn{3}{|c|}{ Antunovac } & \multicolumn{3}{|c|}{ Cerić } \\
\hline Kultivar (K): & \multicolumn{3}{|c|}{$\begin{array}{l}4,75 \\
4,31\end{array}$} & \multicolumn{3}{|c|}{$\begin{array}{l}4,85 \\
5,07\end{array}$} \\
\hline F-test: & \multicolumn{3}{|c|}{$7737 *$} & \multicolumn{3}{|c|}{$4,557^{*}$} \\
\hline $\begin{array}{r}\operatorname{LSD}_{0,05} \\
0,01\end{array}$ & \multicolumn{3}{|c|}{$\begin{array}{l}0,440 \\
0,325\end{array}$} & \multicolumn{3}{|c|}{$\begin{array}{l}0,292 \\
0,216\end{array}$} \\
\hline $\begin{array}{l}\text { Inokulacija } \\
\text { sjemena (I): }\end{array}$ & \multicolumn{3}{|c|}{$\begin{array}{l}4,63 \\
4,44\end{array}$} & \multicolumn{3}{|c|}{$\begin{array}{l}4,48 \\
5,44\end{array}$} \\
\hline F-test: & \multicolumn{3}{|c|}{1,421} & \multicolumn{3}{|c|}{$83,588 * *$} \\
\hline $\begin{array}{r}\operatorname{LSD}_{0,05} \\
0,01\end{array}$ & \multicolumn{3}{|c|}{$\begin{array}{l}0,440 \\
0,325\end{array}$} & \multicolumn{3}{|c|}{$\begin{array}{l}0,292 \\
0,216\end{array}$} \\
\hline $\begin{array}{l}\text { Navodnjavanje (N): } \mathrm{N}_{0} \\
\qquad \mathrm{~N}_{1}\end{array}$ & \multicolumn{3}{|c|}{$\begin{array}{l}4,69 \\
4,38\end{array}$} & \multicolumn{3}{|c|}{$\begin{array}{l}4,76 \\
5,16\end{array}$} \\
\hline F-test: & \multicolumn{3}{|c|}{3,947} & \multicolumn{3}{|c|}{$14,690 * *$} \\
\hline $\begin{array}{r}\operatorname{LSD}_{0,05} \\
0,01\end{array}$ & \multicolumn{3}{|c|}{$\begin{array}{l}0,440 \\
0,325\end{array}$} & \multicolumn{3}{|c|}{$\begin{array}{l}0,292 \\
0,216\end{array}$} \\
\hline Interakcije: & F-test & $\mathrm{LSD}_{0,05}$ & $\mathrm{LSD}_{0,01}$ & F-test & $\mathrm{LSD}_{0,05}$ & $\operatorname{LSD}_{0,01}$ \\
\hline $\mathrm{K} \times \mathrm{I}$ & 1,421 & 0,622 & 0,459 & 2,987 & 0,413 & 0,305 \\
\hline $\mathrm{K} \times \mathrm{N}$ & 1,421 & 0,622 & 0,459 & 0,295 & 0,413 & 0,305 \\
\hline I x N & 0,158 & 0,622 & 0,459 & $88,924 * *$ & 0,413 & 0,305 \\
\hline $\mathrm{K} \times \mathrm{I} \times \mathrm{N}$ & 0,158 & 0,880 & 0,649 & 0,439 & 0,585 & 0,431 \\
\hline
\end{tabular}

$\mathrm{K}_{1}=$ Gold, $\mathrm{K}_{2}=$ Crista; $\mathrm{I}_{0}=$ bez inokulacije sjemena, $\mathrm{I}_{1}=$ inokulacija sjemena;

$\mathrm{N}_{0}=$ bez navodnjavanja, $\mathrm{N}_{1}=$ navodnjavanje; $* \mathrm{p}=0,05$ razina značajnosti, $* * \mathrm{p}=0,01$ razina značajnosti

Biarnes-Dumoulin i sur. (1996.) ističu da su okolišni učinci na prinos zrna važni budući da su sve komponente, uključujući sve interakcije između godine, lokacije i roka sjetve, značajne. U prosjeku pokusa prinosi zrna se kreću od 1,21 do 2,43 $\mathrm{t} \mathrm{ha}^{-1}$, što je u skladu s onima Uzuna i sur. (2005.), ali i znatno niži od prinosa zrna koje navode različiti autori (Croazat, 1994., Popović i sur., 1997., Dore i sur., 1998., Al-Karaki, 1999., Ayaz i sur., 2004.a). 
Irena Rapčan i sur.: Utjecaj kultivara, inokulacije sjemena i navodnjavanja na agronomska svojstva krmnog graška u istočnoj Hrvatskoj

Tablica 6. Prosječne vrijednosti mase 1000 zrna krmnog graška (g) za svaki tretman po lokacijama s pripadajućim F-testom i LSD $(p=0,05$ i p=0,01)

Table 6 Average values of field pea 1000 grain mass (g) for each treatment over locations with belonging F-test and LSD (at $p=0.05$ and $p=0.01$ )

\begin{tabular}{|c|c|c|c|c|c|c|}
\hline Faktor/Lokacija & \multicolumn{3}{|c|}{ Antunovac } & \multicolumn{3}{|c|}{ Cerić } \\
\hline Kultivar (K): & \multicolumn{3}{|c|}{$\begin{array}{l}229,36 \\
186,84\end{array}$} & \multicolumn{3}{|c|}{$\begin{array}{l}235,57 \\
191,99\end{array}$} \\
\hline F-test: & \multicolumn{3}{|c|}{$11,094 * *$} & \multicolumn{3}{|c|}{$93,517 * *$} \\
\hline $\begin{array}{r}\operatorname{LSD}_{0,05} \\
0,01 \\
\end{array}$ & \multicolumn{3}{|c|}{$\begin{array}{l}35,673 \\
26,324\end{array}$} & \multicolumn{3}{|c|}{$\begin{array}{c}12,603 \\
9,300\end{array}$} \\
\hline $\begin{array}{l}\text { Inokulacija } \\
\text { sjemena (I): }\end{array}$ & \multicolumn{3}{|c|}{$\begin{array}{l}178,18 \\
237,99\end{array}$} & \multicolumn{3}{|c|}{$\begin{array}{l}178,21 \\
249,35\end{array}$} \\
\hline F-test: & \multicolumn{3}{|c|}{$21,989 * *$} & \multicolumn{3}{|c|}{$249,238 * *$} \\
\hline $\begin{array}{r}\operatorname{LSD}_{0,05} \\
0,01 \\
\end{array}$ & \multicolumn{3}{|c|}{$\begin{array}{l}35,673 \\
26,324 \\
\end{array}$} & \multicolumn{3}{|c|}{$\begin{array}{c}12,603 \\
9,300\end{array}$} \\
\hline $\begin{array}{r}\text { Navodnjavanje }(\mathrm{N}): \mathrm{N}_{0} \\
\mathrm{~N}_{1}\end{array}$ & \multicolumn{3}{|c|}{$\begin{array}{l}217,86 \\
198,29 \\
\end{array}$} & \multicolumn{3}{|c|}{$\begin{array}{l}217,27 \\
210,29\end{array}$} \\
\hline F-test: & \multicolumn{3}{|c|}{2,357} & \multicolumn{3}{|c|}{2,396} \\
\hline $\begin{array}{r}\operatorname{LSD}_{0,05} \\
0,01 \\
\end{array}$ & \multicolumn{3}{|c|}{$\begin{array}{l}35,673 \\
26,324 \\
\end{array}$} & \multicolumn{3}{|c|}{$\begin{array}{c}12,603 \\
9,300 \\
\end{array}$} \\
\hline Interakcije: & F-test & $\mathrm{LSD}_{0,05}$ & $\mathrm{LSD}_{0,01}$ & F-test & $\mathrm{LSD}_{0,05}$ & $\operatorname{LSD}_{0,01}$ \\
\hline $\mathrm{K} \times \mathrm{I}$ & 2,504 & 50,449 & 37,228 & $23,730 * *$ & 17,824 & 13,153 \\
\hline $\mathrm{K} \times \mathrm{N}$ & $7,277^{*}$ & 50,449 & 37,228 & $30,261 * *$ & 17,824 & 13,153 \\
\hline I x N & $10,080^{* *}$ & 50,449 & 37,228 & $31,775^{* *}$ & 17,824 & 13,153 \\
\hline $\mathrm{K} \times \mathrm{I} \times \mathrm{N}$ & 0,355 & 71,346 & 52,649 & 0,000 & 25,207 & 18,601 \\
\hline
\end{tabular}

$\mathrm{K}_{1}=$ Gold, $\mathrm{K}_{2}=\mathrm{SW}$ Crista; $\mathrm{I}_{0}=$ bez inokulacije sjemena, $\mathrm{I}_{1}=$ inokulacija sjemena;

$\mathrm{N}_{0}$ = bez navodnjavanja, $\mathrm{N}_{1}=$ navodnjavanje; * $\mathrm{p}=0,05$ razina značajnosti, $* * \mathrm{p}=0,01$ razina značajnosti

Silim i sur. (1992.) navode da prinosi graška jako ovise o okolišnim uvjetima poput suše, posebno u cvatnji i nalijevanju mahuna. U umjereno suhim područjima stres vode predstavlja glavni čimbenik smanjenja prinosa (Martin i sur., 1994.). Rathi i sur. (1995.) zaključuju da se navodnjavanje u cvatnji pokazalo obećavajućim za prinose sjemena uglavnom zbog povećanja broja mahuna po biljci i broja sjemena po mahuni. 
Irena Rapčan i sur.: Utjecaj kultivara, inokulacije sjemena i navodnjavanja na agronomska svojstva krmnog graška u istočnoj Hrvatskoj

Tablica 7. Prosječne vrijednosti prinosa zrna krmnog graška (t/ha) za svaki tretman po lokacijama s pripadajućim F-testom i LSD $(p=0,05$ i $p=0,01)$

Table 7 Average values of field pea grain yield $\left(\mathrm{t} \mathrm{ha}^{-1}\right)$ for each treatment over locations with belonging LSD and (at $p=0.05$ and $p=0.01$ )

\begin{tabular}{|c|c|c|c|c|c|c|}
\hline Faktor/Lokacija & \multicolumn{3}{|c|}{ Antunovac } & \multicolumn{3}{|c|}{ Cerić } \\
\hline Kultivar (K): & & $\begin{array}{l}1,91 \\
1,52 \\
\end{array}$ & & & $\begin{array}{l}2,06 \\
1,74\end{array}$ & \\
\hline F-test: & & 3,272 & & & $4,804^{* *}$ & \\
\hline $\begin{array}{r}\operatorname{LSD}_{0,05} \\
0,01\end{array}$ & & $\begin{array}{l}0,592 \\
0,437\end{array}$ & & & $\begin{array}{l}0,156 \\
0,115\end{array}$ & \\
\hline $\begin{array}{l}\text { Inokulacija } \\
\text { sjemena (I): }\end{array}$ & & $\begin{array}{l}1,21 \\
2,22\end{array}$ & & & $\begin{array}{l}1,37 \\
2,43\end{array}$ & \\
\hline F-test: & & $22,489 *$ & & & $61,923 * *$ & \\
\hline $\begin{array}{r}\operatorname{LSD}_{0,05} \\
0,01\end{array}$ & & $\begin{array}{l}0,592 \\
0,437\end{array}$ & & & $\begin{array}{l}0,156 \\
0,115\end{array}$ & \\
\hline $\begin{array}{l}\text { Navodnjavanje (N): } \mathrm{N}_{0} \\
\qquad \mathrm{~N}_{1}\end{array}$ & & $\begin{array}{l}1,88 \\
1,55\end{array}$ & & & $\begin{array}{l}1,82 \\
1,98\end{array}$ & \\
\hline F-test: & & 2,400 & & & $9,138 * *$ & \\
\hline $\begin{array}{r}\operatorname{LSD}_{0,05} \\
0,01\end{array}$ & & $\begin{array}{l}0,592 \\
0,437\end{array}$ & & & $\begin{array}{l}0,156 \\
0,115\end{array}$ & \\
\hline Interakcije: & F-test & $\mathrm{LSD}_{0,05}$ & $\mathrm{LSD}_{0,01}$ & F-test & $\mathrm{LSD}_{0,05}$ & $\operatorname{LSD}_{0,01}$ \\
\hline $\mathrm{K} \times \mathrm{I}$ & 1,867 & 0,838 & 0,613 & $11,900 * *$ & 0,220 & 0,162 \\
\hline $\mathrm{K} \times \mathrm{N}$ & $6,883^{*}$ & 0,838 & 0,618 & $30,689 * *$ & 0,220 & 0,162 \\
\hline I x N & $10,101 * *$ & 0,838 & 0,618 & $66,737 * *$ & 0,220 & 0,162 \\
\hline $\mathrm{K} \times \mathrm{I} \times \mathrm{N}$ & 0,575 & 1,185 & 0,874 & 0,750 & 0,311 & 0,230 \\
\hline
\end{tabular}

$\mathrm{K}_{1}=$ Gold, $\mathrm{K}_{2}=\mathrm{SW}$ Crista; $\mathrm{I}_{0}=$ bez inokulacije sjemena, $\mathrm{I}_{1}=$ inokulacija sjemena;

$\mathrm{N}_{0}=$ bez navodnjavanja, $\mathrm{N}_{1}=$ navodnjavanje; $* \mathrm{p}=0,05$ razina značajnosti, $* * \mathrm{p}=0,01$ razina značajnosti

Sadržaj bjelančevina u zrnu kretao se od 25,85 do $26,65 \%$ na lokaciji Antunovac (Grafikon 1.). Najviši sadržaj bjelančevina ostvario je kultivar SW Crista u uvjetima navodnjavanja (26,65\%), dok je najniži utvrđen kod istog kultivara u uvjetima navodnjavanja i inokulacije u kontroli te kod kultivara Gold pri inokulaciji $(25,85 \%)$. Na lokaciji Cerić (Grafikon 2.) najviši sadržaj bjelančevina utvrđen je kod kultivara Gold u kontroli (27,40\%), a najmanji kod kultivara SW Crista u uvjetima navodnjavanja $(25,10 \%)$. 
Irena Rapčan i sur.: Utjecaj kultivara, inokulacije sjemena i navodnjavanja na agronomska svojstva krmnog graška u istočnoj Hrvatskoj

\section{Sadržaj bjelančevina}

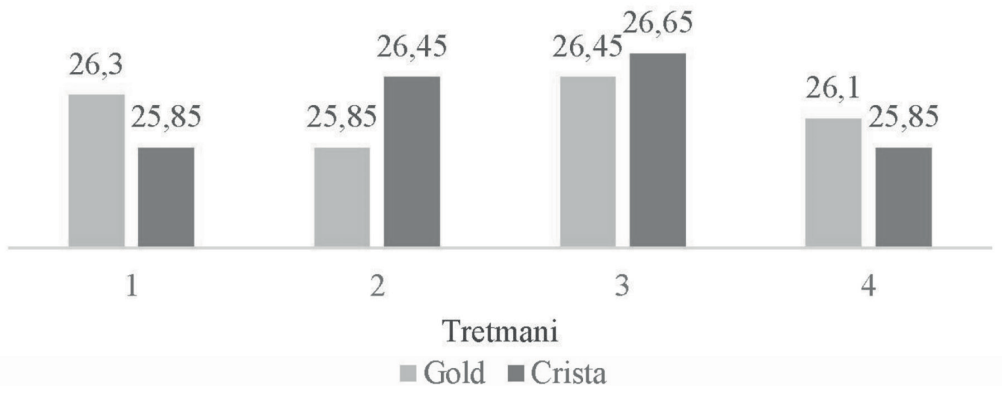

Grafikon 1. Sadržaj bjelančevina (\%) kultivara Gold i Crista na lokaciji Antunovac

Graph 1 Protein content (\%) of Gold and Crista cultivars at Antunovac

Tretman 1: Kontrola; Tretman 2: Inokulacija; Tretman 3: Navodnjavanje; Tretman 4: Navodnjavanje i inokulacija

Wang i Daun (2004.) navode da kultivar, lokacija i okolišni uvjeti odnosno uvjeti rasta značajno utječu na kakvoću i sastav sjemena mahunarki. Čini se da je sadržaj bjelančevina posebno osjetljiv na okolišni stres poput oborina, intenziteta svjetlosti, dužine vegetacijske sezone, dužine dana i temperature kao i agronomskih čimbenika poput sklopa, korova i plodnosti tla, kako navode isti autori. Vrijednosti dobivene u ovom istraživanju su u skladu s onima koje navode Ottoson (1984.) od 22 do $28 \%$, Igbasan i sur. (1996.) od 22,3 do 26,6\% i Vidal-Valverde i sur. (2003.) od 26 do $32 \%$ sadržaja bjelančevina u zrnu.

\section{Sadržaj bjelančevina}

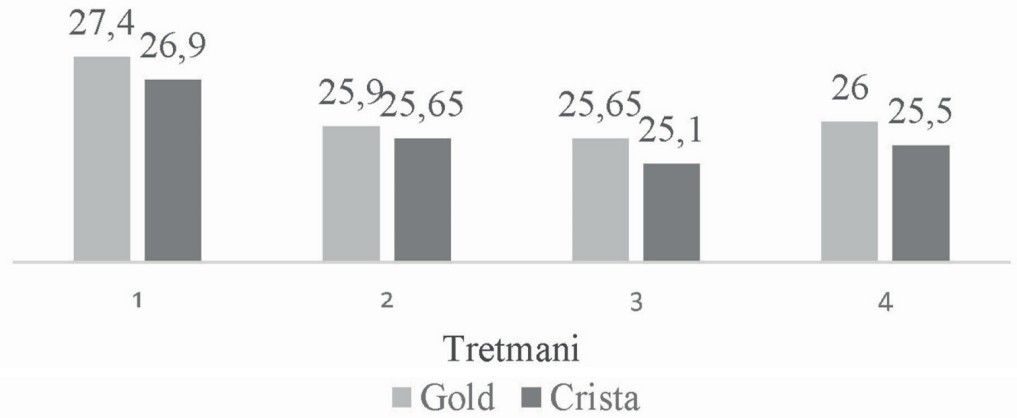

Grafikon 2. Sadržaj bjelančevina (\%) kultivara Gold i Crista na lokaciji Cerić

Graph 2 Protein content (\%) of Gold and Crista cultivars at Cerić

Tretman 1: Kontrola; Tretman 2: Inokulacija; Tretman 3. Navodnjavanje; Tretman 4: Navodnjavanje i inokulacija 
Irena Rapčan i sur.: Utjecaj kultivara, inokulacije sjemena i navodnjavanja na agronomska svojstva krmnog graška u istočnoj Hrvatskoj

\section{ZAKLJUČAK}

Godina istraživanja (2014.) bila je vrlo neuobičajena po količini i rasporedu oborina na obje ispitivane lokacije (Antunovac i Cerić), što je vjerojatno utjecalo na ispitivana svojstva. Poljsko nicanje u prosjeku po tretmanima pokusa iznosilo je $61,02 \%$ odnosno $63,38 \%$ ovisno o lokaciji, a na ove vrijednosti najviše su utjecali kultivar i navodnjavanje, dok inokulacija sjemena nije imala utjecaja. Na broj mahuna po biljci (u prosjeku 2,67) na lokaciji u Antunovcu utjecala je inokulacija sjemena, a na lokaciji u Ceriću (u prosjeku 2,83 ) utjecali su kultivar i navodnjavanje. Broj zrna po mahuni kretao se od 4,31 do 5,44 ovisno o tretmanu pokusa i lokaciji, a prosječno veći broj zrna po mahuni dobiven je na lokaciji Cerić, gdje je utjecaj kultivara bio na razini 5\%, a inokulacije sjemena i navodnjavanja na razini $1 \%$. Masa 1000 zrna iznosila je od 178,18 do $249,35 \mathrm{~g}$, ovisno o tretmanu i lokaciji, a na ovo svojstvo jedino navodnjavanje nije imalo statistički značajnog utjecaja. Prinos zrna bio je znatno niži od vrijednosti navedenih u literaturi s tim da su najmanje vrijednosti dobivene $u$ tretmanu bez inokulacije sjemena, a najveće $u$ tretmanu $s$ inokulacijom sjemena. U cilju utvrđivanja reakcija različitih kultivara krmnog graška na inokulaciju i navodnjavanje $u$ istočnoj Hrvatskoj, kao i na drugim područjima, potrebna su dodatna istraživanja, jer podaci ukazuju da postoji mogućnost povećanja prinosa i kvalitete krmnog graška primjenom odgovarajućeg kultivara, inokulacije sjemena i navodnjavanja.

\section{LITERATURA}

1. Acikgoz1, E., Ustun, A., Gul, I., Anlarsal, E.,Tekeli, A.S., Nizam, I., Avcioglu, R., Geren, H., Cakmakci, S., Aydinoglu, B.,Yucel, C., Avci, M., Acar, Z., Ayan, I., Uzun, A., Bilgili, U., Sincik, M., Yavuz, M. (2009.): Genotype $\times$ environment interaction and stability analysis for dry matter and seed yield in field pea (Pisum sativum L.). Spanish Journal of Agricultural Research 7(1): 96-106.

2. Al-Karaki, G.N. (1999.): Phenological development-yield relationship in dry pa in semiarid Mediterranean conditions. Journal of Agronomy and Crop Science 182:73-75.

3. Ayaz, S., McKenzie, B.A., Hill, G.D., McNeil, D.L. (2004.a): Variability in yield of four grain legume species in a subhumid temperate environment. I. Yields and harvest indeks. Journal of Agricultural Science 142:9-19.

4. Ayaz, S., McKenzie, B.A., Hill, G.D., McNeil, D.L. (2004.b): Variability in yield of four grain legume species in a subhumid temperate environment. II. Yield components. Journal of Agricultural Science 142:21-28. 
Irena Rapčan i sur.: Utjecaj kultivara, inokulacije sjemena i navodnjavanja na agronomska svojstva krmnog graška u istočnoj Hrvatskoj

5. Biarnes-Dumoulin V., Denis J.-P., Lejeune-Henaut I., Eteve G. (1996.): Interpreting yield instability in pea using genotypic and environmental covariates. Crop Science 36:115-120.

6. Croazat Y., Aveline A., Coste F., Gillet J.P., Domenach A.M. (1994.): Yield performance and seed production pattern of field-grown pea and soybean in relation to N nutrition. European Journal of Agronomy 3(2):135-144.

7. Dore T., Meynard J.M., Sebillotte M. (1998.): The role of grain numer, nitrogen nutrition and stem number in limiting pea crop (Pisum sativum) yields under agricultural conditions. European Journal of Agronomy 8:29-37.

8. Državni hidrometeorološki zavod Republike Hrvatske (2015.): Annual report for 2014. Available at: www.dhmz.htnet.hr [Accessed 5 September 2015].

9. Državni zavod za statistiku. Annual report for 2014. Available at: www.dzs.hr [Accessed 5 September 2015].

10. Food and Agriculture Organization of the United Nations (2015.): Annual report for 2014. Available at: www.fao.org.faostat [Accessed 1 December 2015].

11. Igbasan, F.A., Guenter, W., Warkentin, T.D., McAndrew, D.W. (1996.): Protein quality of peas as influenced by location, nitrogen application and seed inoculation. Plant Foods for Human Nutrition 49(2):93-105.

12. Kovač; K. (1994.): The effect of some intensification factors on the pea yield of intermediary type in maize-growing region (Czech). Rostlinna Vyroba 40(10):949-956.

13. Krizmanić, G., Čupić, T., Tucak, M., Popović, S. (2016.): Korelacijski odnosi prinosa i komponenti prinosa u oplemenjivačkom ciklusu jarog stočnog graška. Proceedings $51^{\text {st }}$ Croatian and $11^{\text {th }}$ International Symposium on Agriculture, 155-159, Opatija.

14. Martin, I., Tenorio, J.L., Ayerbe, L. (1994.): Yield, growth and water use of conventional and semileafless peas in semiarid environment. Crop Science 34:1576-1583.

15. McPhee K.E., Muehlbauer F.J. (1999.): Variation for biomass and residue production by dry pea. Field Crops Research 62:203-212.

16. Ottoson, L. (1984.): The protein content of vining peas during the maturation. ISHS Acta Horticulturae 163:71-78.

17. Poggio S.L., Satorre E.H., Dethiou S., Gonzalo G.M. (2005.): Pod and seed numbers as a function of photothermal quotient during the seed set period of field pea (Pisum sativum). European Journal of Agronomy 22(1):55-69. 
Irena Rapčan i sur.: Utjecaj kultivara, inokulacije sjemena i navodnjavanja na agronomska svojstva krmnog graška u istočnoj Hrvatskoj

18. Popović, S, Sonja Grljušić, Stjepanović, M., Gordana Bukvić (1997.): Proizvodnja graška za zrno i voluminoznu krmu. Zbornik radova XXXIII znanstvenog skupa hrvatskih agronoma, Pula, p. 63.

19. Rapčan. I. (2002.): Prinos graška u zavisnosti od roka sjetve, sklopa i gnojidbe dušikom. Magistarski rad, Poljoprivredni fakultet u Osijeku, Osijek.

20. Rapčan, I.; Jurišić, M.; Rozman, V. (2003.): Prinos i neka fenotipska svojstva graška (Pisum sativum ssp. arvense L.) u zavisnosti od roka sjetve, sklopa i gnojidbe dušikom na području Osijeka. Sjemenarstvo 20(3-4):131-145.

21. Rapčan, I. (2006.): Laboratorijska kakvoća kultivara graška i njezin utjecaj na prinos zrna i zelene mase. Disertacija, Poljoprivredni fakultet u Osijeku, Osijek.

22. Rapčan Irena, Gordana Bukvić, Sonja Grljušić, Tihana Teklić, Jurišić, M. (2006.): Produkcija biomase krmnog graška (Pisum sativum L.) u zavisnosti od starosti sjemena i agroekoloških uvjeta uzgoja. Poljoprivreda 12(2):29-35.

23. Rathi, G.S., Sharma, R.S., Rajak, R.C. (1995.): Effect of irrigation schedule and phosphorus on yield attributes and yield of field pea (Pisum sativum). Indian Journal of Agronmy 40(1):82-85.

24. Silim, S.N., Hebblethwaite, P.D., Jones, C. (1992.): Irrigation and water use in leafless peas (Pisum sativum). Journal of Agricultural Science 119:211-222.

25. Stjepanović, M.; Čupić, T.; Gantner, R. (2012.): Grašak. Poljoprivredni fakultet u Osijeku i Poljoprivredni institut Osijek, Osijek.

26. Uzun, A., Bilgili, U., Sincik, M., Filya, I., Acikgoz, E. (2005.): Yield and quality of forage type pea lines of contrasting leaf types. European Journal of Agronomy 22(1):85-94.

27. Vidal-Valverde, C., Frias, J., Hernandez, A., Martin-Alvarez, P.J., Sierra, I., Rodriguez, C., Blazquez, I., Vicente, G. (2003.): Assessment of nutritional compounds and antinutritional factors in pea (Pisum sativum) seeds. Journal of the Science of Food and Agriculture 83(4): 298-306.

28. Vukadinović, V. (2012.): Pedološka karta Osječko-baranjske županije. Available at: www.pedologija.com.hr [Accessed 5 September 2015].

29. Wang, N., Daun, J.K. (2004.): Effect of variety and crude protein content on nutrients and certain antinutgrients in field peas (Pisum sativum). Journal of the Science of Food and Agriculture 84(9):1021-1029.

30. TIBCO Software Inc. (2017). Statistica (data analysis software system), version 13. http://statistica.io. 
Irena Rapčan i sur.: Utjecaj kultivara, inokulacije sjemena i navodnjavanja na agronomska svojstva krmnog graška u istočnoj Hrvatskoj

Adrese autora - Author's addresses:

Irena Rapčan, e-mail: irapcan@fazos.hr

Daria Galić Subašić

Monika Marković

Fakultet agrobiotehničkih znanosti Osijek,

Vladimira Preloga 1, 31000 Osijek, Hrvatska

Sonja Grljušić

Poljoprivredni institut Osijek,

Južno predgrađe 17, 31000 Osijek, Hrvatska
Primljeno- Received 20.08.2018. 
Irena Rapčan i sur.: Utjecaj kultivara, inokulacije sjemena i navodnjavanja na agronomska svojstva krmnog graška u istočnoj Hrvatskoj 